\title{
Küratif rezeksiyon yapılan rektum kanseri olgularında ameliyat sonrası sağkalıma etki eden prognostik faktörlerin analizi
}

\author{
Medeni Şermet $^{1}$, Fevzi Celayir ${ }^{2}$, Adil Baykan ${ }^{3}$
}

\begin{abstract}
ÖZET:
Küratif rezeksiyon yapılan rektum kanseri olgularında ameliyat sonrası sağkalıma etki eden prognostik faktörlerin analizi

Amaç: Rektum kanseri nedeniyle ameliyat ettiğimiz hastalarda prognostik faktörlerin yaşam süresi üzerine etkilerinin incelenmesi.

Yöntem: Ocak 2004-Aralık 2010 yılları arasında Şişli Etfal Eğitim ve Araştırma Hastanesi 1.Genel Cerrahi Kliniğinde rektum kanseri nedeniyle opere edilen 112 hastadan küratif rezeksiyon uygulanan 80 hastanın klinik kayıtları retrospektif olarak incelendi. Yaş, cinsiyet, vücut kitle indeksi, uygulanan ameliyat şekli, tümör lokalizasyonu, tümör boyutu, tümörün makroskopik tipi, tümörün evresi (TNM Sınıflaması), histolojik tip ve diferansiasyon derecesi, çevresel cerrahi sınır pozitifiği (ÇCS), vasküler invazyon, perinöral invazyon, lenf bezi tutulumu, preoperatif neoadjuvan tedavi, postoperatif adjuvan tedavi, ameliyat öncesi tümör belirteçleri; CEA (N:0,0-3,0), CA19-9 (N:0-35U/ML), hemoglobin, albumin düzeyleri prognostik parametre olarak belirlenip 5 yıllık sağkalıma olan etkileri değerlendirildi.

Bulgular: Hastaların 42'si erkek, 38'i kadın ve yaş ortalamaları 57,8 111.0 (20-79yaş) idi. Hastaların verileri univaryans analizle incelendiğinde; Yaygın rektum tutulumu olanlar, tümör boyutunun 5 cm'den büyük olması, evre III-IV tümörü olanlar, çevresel cerrahi sınırda tümör olanlar, perinöral ve vasküler invazyonu olanlar, lenf bezi pozitif saptananlar, ameliyat öncesi CEA düzeyi yüksek olanlar ile WHO sınıflamasına göre Malign Melanom ve Skuamoz hücreli karsinom olanların daha kısa süreli yaşadığı belirlendi. Bu faktörler Lojistik regresyon analizi ile incelendiğinde bağımsız prognostik faktörler olduğu saptandı.

Sonuç: Çalışmamızda yaygın rektum tutulumu,tümör boyutu, tümörün evresi, perinöral ve vasküler invazyonu, pozitif lenf nodu sayısı, CEA düzeyi, çevresel cerrahi sınır pozitifliği ve tümörün histolojik tipi bağımsız prognostik faktörler olarak bulunmuştur. Ancak sağkalım üzerinde bu parametrelerin etkilerini daha net ortaya koyabilmemiz için vaka serimizin ve erken evre hastalarımızın sayısının artmasına ve cerrahi tekniğin standardizasyonuna intiyaç vardır.

Anahtar kelimeler: Rektum kanseri, prognostik faktörler
\end{abstract}

\section{ABSTRACT:}

The analysis of the prognostic factors affecting survival after the curative resection in patients with rectal cancer

Objective: In this study we investigate the effects of the prognostic factors on the patients' life expectancy whom underwent surgery for rectal cancer.

Methods: Between January 2004-December 2010, 112 patients were operated for rectal cancer at Şişli Etfal Traning and Reserach Hospital, FirstGeneral Surgery Clinic. 80 patients underwent curative resection. Their clinical records were retrospectively reviewed.

Age, gender, body mass index, operation type, tumor location, tumor size, macroscopic type, tumor stage (TNM classification), histological type and degree of differentiation, circumferential resection margin (CRM), vascular invasion, perineural invasion, lymph node involvement, preoperative neoadjuvant therapy, postoperative adjuvant therapy, preoperative tumor markers, $\mathrm{CEA}(\mathrm{N}: 0,0-3,0)$, CA19-9 (N: 0-35U / ML), hemoglobin, serum albumin levels were identified as prognostic parameters. Their effects of 5-year survival were evaluated.

Results: There were 42 males and 38 females, mean age 57.8 \pm 11.0 years (age 20-79, Patient data were analyzed by univariate analysis. Patients who had extensive involvement of the rectum, tumor size larger than $5 \mathrm{~cm}$, stage III-IV tumors, CRM positive, perineural and vascular invasion, Iymph node positive, with high preoperative CEA levels according to the WHO classification and Malignant Melanoma or squamous cell carcinoma were short survival times. These factors were found to be independent prognostic factors were investigated by logistic regression analysis.

Conclusion: In our study, extensive involvement of the rectum, tumor size, tumor stage, perineural and vascular invasion, number of positive lymph nodes, CEA levels, positive CRM and tumor histological type were found to be independent prognostic factors. However, the effects of these parameters on survival should be more clearly. Therefore, it needs to increase the number of our patients and also the early stage patients and standardization of the surgical technique is required. Key words: Rectal cancer, prognostic factors
'Op. Dr., Balıklıgöl Devlet Hastanesi, Genel Cerrahi Servisi, Şanlıurfa-Türkiye ${ }^{2} O p$. Dr., Şişli Etfal Hastanesi Genel Cerrahi Kliniği, İstanbul-Türkiye

${ }^{3}$ Prof. Dr., Özel Medistate Hastanesi, İstanbul-Türkiye

Yazışma Adresi / Address reprint requests to: Dr. Medeni Şermet, Şanlıurfa Balıklıgöl Devlet Hastanesi, Genel Cerrahi Kliniği 63000 Merkez, Şanlıurfa-Türkiye

Telefon / Phone: +90-507-236-7020

E-posta / E-mail:

m-sermet@hotmail.com

Geliş tarihi / Date of receipt: 15 Ocak 2013 / January 15, 2013 


\section{GíRiş}

Rektum kanseri, insanlardaki en agresif tümörlerden biridir ve erken evrede teşhis edildiği zaman izlenen 5 yıllık sağ kalım oranı \%80-90 iken, ileri evre tümörlerde bu oran \%15-25'lere kadar gerilemektedir (1). Rektum kanseri, dünyada erkeklerde 3., kadınlarda 2. en sık görülen kanserdir. Türkiye'de tüm kanserler içinde erkeklerde 4. kadınlarda 5. en sık görülen kanserdir. Türkiye'de saptanan kanserlerin erkeklerde \%7.4, kadınlarda \%6'sı rektum kanseridir. Türkiye'de rektum kanserinden ölüm oranı erkeklerde 4.3/100.000, kadınlarda 2.5/100.000'dir (2).

Rektum kanserine erkeklerde ve kadınlarda birbirine yakın rastlanır ve erkek kadın oranı 1,2/1'dir. 40 yaşından önce nadir görülen hastalığın insidansı yaşla birlikte artar ve $60^{\prime}$ lı yaşlarda en yüksek seviyesine ulaşır. Tüm dünyada yürütülen toplum taramaları nedeniyle hastalık daha erken evrede teşhis edilmeye başlanmıştır.

Rektum kanserinde prognoz ile ilgili yapılmış çalışmalarda bazı faktörlerin prognoza etkisi hemen her zaman gözlenmekle birlikte bazı faktörler, değişik araştırmalar arasında farklılıklar göstermektedir.

Rektum kanserlerinde prognoz üzerine etkili olduğu düşünülen birçok faktör araştırma konusu olmuştur. Cinsiyet, yaş, kan grubu ve kan transfüzyonu, vücut kitle indeksi, tümörün lokalizasyonu, tümörün çapı, makroskopik tipi, histolojik grade, evresi, metastatik lenf nodu, tümör belirteçleri (CEA, CA199), ameliyat öncesi hemoglobin ve albümin düzeyi, uygulanan ameliyat tipi, lenf disseksiyonu ve pozitif lenf nodu sayısı, kemoterapi (var/yok), radyoterapi (var/yok) rezeksiyon yapılan rektum kanseri hastalarında prognostik faktörler olarak araştırılmıştır.

Bu çalışmada öne sürülen prognostik faktörlerin retrospektif olarak değerlendirilerek sağ kalım üzerine etkileri araştırılmıştır.

\section{GEREÇ VE YÖNTEM}

Ocak-2004 ve Aralık-2010 tarihleri arasında Şişli Etfal Eğitim ve Araştırma Hastanesi 1. Genel Cerrahi Kliniğinde rektum kanseri tanısıyla küratif rezeksiyon uygulanan 112 hastanın klinik kayıtları, patoloji ve ameliyat raporları retrospektif olarak incelendi. 80 hastanın kaydı çalışmamıza uygun bulunarak değerlendirmeye alındı. Opere olan bu hastalarda sağ kalıma etki eden prognostik faktörleri araştırmak amacıyla; cinsiyet, yaş, vücut kitle indeksi (VKi), tümör lokalizasyonu, tümör boyutu, tümörün makroskopik tipi, tümörün evresi (TNM sınıflaması), histolojik tip ve diferansiyasyon derecesi, çevresel cerrahi sınırda (ÇCS) pozitifliği, vasküler invazyon, perinöral invazyon, lenf nodu tutulumu, preoperatif neoadjuvan tedavi, postoperatif adjuvan tedavi, ameliyat öncesi tümör belirteçleri; CEA (N:0,0-3,0), Ca19-9(N:0$35 \mathrm{U} / \mathrm{ml})$, hemoglobin $(\mathrm{N}: 10.0-18.0 \mathrm{~g} / \mathrm{dl})$, albumin $(\mathrm{N}: 3.4-4.8 \mathrm{gr} / \mathrm{dl})$ düzeyleri prognostik parametre olarak belirlenip değerlendirildi. Mevcut prognostik faktörlerin 5 yıllık sağ kalım üzerine etkileri araştırıldı. Aşağıdaki kriterlere uyan hastalar çalışma dışı bırakıldı:

- Karaciğer ve akciğer metastazı bulunması

- Peritoneal karsinomatozis varlığı

- Komşu organ invazyonu

- Yetersiz lenf bezi disseksiyonu

- Daha önce rektum kanseri nedeniyle opere edilmiş hastalar

Yaş grupları 0-40, 40-60 ve 60 yaş üzeri şeklinde 3 gruba ayrıldı.Uygulanan ameliyat şekli low anterior rezeksiyon (LAR) ve very low anterior rezeksiyon (VLAR) şeklinde 2 grup olarak sınıflandırıldı. Vücut kitle indeksi (VKi) normal olanlar ve > 30 olanlar olarak iki grupta incelendi.

Lokalizasyon, 0-5.cm arası distal rektum, 5-10 cm orta rektum, $10 . \mathrm{cm}$ üzeri proksimal rektum olarak sınıflandırıldı.Tümör boyutunu 0-5 cm, 5-10 cm ve 10 cm'den büyük olmak üzere 3 gruba ayrıldı. Tümörün makroskopik tipi Polipoid Vejetatif Ülseroinfiitratif olarak sınıflandırıldı. Hastalarımızın çıkarılan ve metastatik olan lenf bezi sayılarına da bakıldı. Hastalar lenf bezi negatif, 1-3 arası ve 4'ten daha fazla metastaik lenf bezi çıkarılan hastalar olmak üzere 3 gruba ayrıldı. Histolojik tip Adenokarsinom Müsinöz ve Diğer olarak 3 grupta ve diferansiyasyon derecesi orta, iyi ve az diferansiye şeklinde, vasküler invazyon var/yok, perinöral invazyon var/yok şeklinde gruplara ayrıldı. Çevresel cerrahi sınır ölçülürken tümör penetrasyonunun en derin olduğu sınıra mikroskobik olarak $1 \mathrm{~mm}$ yakınında tümör varlı̆̆ı pozitif kabul edildi. 
Tablo 1: TNM sınıflaması ve evreler

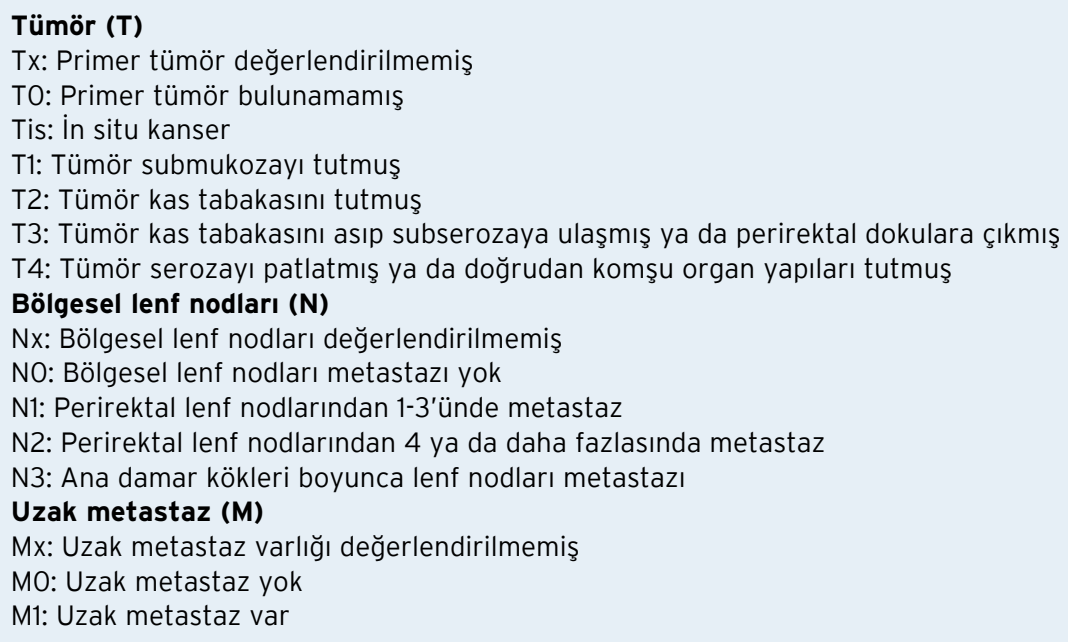

TNM sınıflamasına göre oluşan evreler Tablo 2'de gösterilmiştir.

\section{Tablo 2: TNM sınıflamasına göre evreler}

\begin{tabular}{ll}
\hline Evre & T N $\mathbf{M}$ \\
\hline 0 & Tis NO MO \\
I & T1 NO MO \\
& T2 NO MO \\
IIA & T3 NO MO \\
IIB & T4 NO MO \\
IIIA & T1,2 N1 MO \\
IIIB & T3,4 N1 MO \\
IIIC & Herhangi T N2 MO \\
IV & Herhangi T Herhangi N M1
\end{tabular}

TNM evresinin Uluslararası Kanser Birliği ve Amerikan Birleşik Kanser Komitesi (American Joint Committee on Cancer) ve Kansere Karşı Uluslar arası Birlik (Union Internationale Contre Le Cancer) çalışma gruplarının ortalama 5 yılda bir gözden geçirdikleri bu sınıflamanın son şekli 2002 yılında yayınlanmıştır

TNM sınıflaması Tablo 1'de verilmiştir. Sağkalımlar hasta ve yakınlarıyla birebir görüşme yapılarak tespit edildi.

Çalışmada elde edilen bulgular değerlendirilirken, istatistiksel analizler için SPSS (Statistical Package for Social Sciences) for Windows 15.0 programı kullanıldı. Çalışma verileri değerlendirilirken tanımlayıcı istatistiksel metodların (ortalama, standart sapma, frekans) yanısıra niceliksel verilerin karşılaştırılmasında normal dağılım gösteren paramet- relerin karşılaştırılmasında Student t testi; normal dağılım göstermeyen parametrelerin karşılaştırılmasında Mann Whitney $U$ testi kullanıldı. Niteliksel verilerin karşılaştırılmasında ise Ki-Kare testi kullanıldı. Sağkalım analizlerinde Kaplan-Meier analizi ve Log Rank testi kullanıldı. Parametrelerin mortalite üzerine toplu halde etkilerinin incelenmesinde Lojistik regresyon analizi kullanıldı. Sonuçlar \%95'lik güven aralığında, anlamlılık $\mathrm{p}<0.05$ düzeyinde değerlendirildi.

\section{BULGULAR}

Çalışmaya toplam 80 hasta dahil edildi. Hastaların yaş ortalaması $57,8 \pm 11.0$ olup (en küçüğü 20 , en büğüğü 79 yaşında) çoğunluğu 60 yaşından büyük idi (\%55). E/K oranı 1.1 bulundu. Vücut kitle indeksleri incelendiğinde hastaların genel olarak normal kilolu olduğu görüldü $(\% 71,69)$.

Hastaların çoğunluğu TNM sınıflamasına göre evre III $(\% 61,25)$ idi. Tümör lokalizasyonuna bakıldığında en sık alt rektum yerleşimli olduğu görüldü $(\% 45,0)$. Makroskopik olarak en sık ülseroinfiltratif tip (\%68,75), mikroskopik olarak WHO sınıflamasına göre en sık adenokarsinom $(\% 57,50)$ olarak saptandı. 39 hastada $(\% 48,75)$ vasküler invazyon saptandı, 42 hastada $(\% 52,50)$ perinoral invazyon saptandı. Diferansiye oranlarında az diferansiye tümör 
Tablo 3: Prognostik faktörlerin log rank testi ile değerlendirilmesi.

\begin{tabular}{|c|c|c|c|c|c|c|c|}
\hline \multirow[b]{2}{*}{ Yaş } & \multicolumn{2}{|c|}{$\begin{array}{l}\text { Sağ kalım } \\
\text { Ort } \pm \text { SE }\end{array}$} & \multirow{2}{*}{$\begin{array}{c}\mathbf{P} \\
0,197\end{array}$} & \multirow[b]{2}{*}{$\begin{array}{c}\text { Tümör } \\
\text { Lokalizasyonu }\end{array}$} & \multicolumn{2}{|c|}{$\begin{array}{l}\text { Sağ kalım } \\
\text { Ort } \pm \text { SE }\end{array}$} & \multirow{2}{*}{$\begin{array}{c}\mathbf{P} \\
0,127\end{array}$} \\
\hline & $\begin{array}{c}<40 \\
40-60 \\
>60\end{array}$ & $\begin{array}{l}47,60 \pm 10,11 \\
22,82 \pm 3,05 \\
36,72 \pm 3,29\end{array}$ & & & $\begin{array}{l}\text { Alt Rektum } \\
\text { Orta Rektum } \\
\text { Üst Rektum }\end{array}$ & $\begin{array}{c}38,80 \pm 5,42 \\
34,62 \pm 6,21 \\
8,47 \pm 3,15\end{array}$ & \\
\hline Cinsiyet & $\begin{array}{l}\text { Kadın } \\
\text { Erkek }\end{array}$ & $\begin{array}{l}39,02 \pm 5,16 \\
32,73 \pm 4,05\end{array}$ & 0,317 & $\begin{array}{l}\text { Tümörün } \\
\text { Evresi }\end{array}$ & $\begin{array}{l}\text { I } \\
\text { II } \\
\text { III } \\
\text { IV }\end{array}$ & $\begin{array}{c}56,70 \pm 6,07 \\
39,90 \pm 6,45 \\
26,90 \pm 3,94 \\
10,00 \pm 6,9\end{array}$ & $0,009 * *$ \\
\hline $\begin{array}{l}\text { Vücut Kitle } \\
\text { İndeksi }\end{array}$ & $\begin{array}{l}\text { Zayıf } \\
\text { Normal } \\
\text { Şişman }\end{array}$ & $\begin{array}{c}32,34 \pm 5,39 \\
35,93 \pm 3,93 \\
18,18 \pm 2,91\end{array}$ & 0,919 & $\begin{array}{l}\text { Tümörün } \\
\text { Boyutu }\end{array}$ & $\begin{array}{l}<5 \mathrm{~cm} \\
>5 \mathrm{~cm}\end{array}$ & $\begin{array}{l}51,30 \pm 6,19 \\
24,69 \pm 3,17\end{array}$ & $0,035^{*}$ \\
\hline $\begin{array}{l}\text { Neoadjuvan } \\
\text { Tedavi }\end{array}$ & & $34,89 \pm 3,70$ & 0,657 & $\begin{array}{l}\text { Vasküler } \\
\text { İnvazyon }\end{array}$ & $\begin{array}{l}\text { Var } \\
\text { Yok }\end{array}$ & $\begin{array}{l}26,74 \pm 3,86 \\
47,58 \pm 4,68\end{array}$ & $0,002 * *$ \\
\hline $\begin{array}{l}\text { Adjuvan } \\
\text { Tedavi }\end{array}$ & & $40,18 \pm 4,85$ & 0,252 & $\begin{array}{l}\text { Perinöral } \\
\text { İnvazyon }\end{array}$ & $\begin{array}{l}\text { Var } \\
\text { Yok }\end{array}$ & $\begin{array}{l}26,12 \pm 3,82 \\
46,76 \pm 4,58\end{array}$ & $0,001^{* *}$ \\
\hline $\begin{array}{l}\text { Neoadjuvan+ } \\
\text { Adjuvan } \\
\text { Tedavi }\end{array}$ & & $35,80 \pm 5,09$ & 0,007 & Makroskobik Tip & $\begin{array}{c}\text { Polipoid } \\
\text { Vejetatif } \\
\text { ÜIseroinfiitratif }\end{array}$ & $\begin{array}{l}16,00 \pm 4,90 \\
33,28 \pm 9,27 \\
39,44 \pm 3,90\end{array}$ & 0,060 \\
\hline $\begin{array}{l}\text { Yapılan } \\
\text { Ameliyat }\end{array}$ & $\begin{array}{l}\text { LAR } \\
\text { VLAR }\end{array}$ & $\begin{array}{l}58,40 \pm 5,04 \\
27,23 \pm 6,46\end{array}$ & 0,439 & $\begin{array}{c}\text { WHO } \\
\text { Sınıflaması }\end{array}$ & $\begin{array}{l}\text { Adenokarsinom } \\
\text { Müsinöz } \\
\text { Diğer }\end{array}$ & $\begin{array}{l}41,49 \pm 5,04 \\
22,12 \pm 4,84 \\
32,00 \pm 4,45\end{array}$ & $0,006 * *$ \\
\hline $\begin{array}{l}\text { Çevresel } \\
\text { cerrahi sınır } \\
\text { (ÇCS) }\end{array}$ & $\begin{array}{l}\text { ÇCS(+) } \\
\text { ÇCS(-)5 }\end{array}$ & $\begin{array}{c}22,27 \pm 3,04 \\
4,14 \pm 5,17\end{array}$ & $0,002 *$ & Grade & $\begin{array}{l}\text { Orta diferansiye } \\
\text { İyi diferansiye } \\
\text { Az diferansiye }\end{array}$ & $\begin{array}{c}33,40 \pm 4,79 \\
18,75 \pm 5,208 \\
15,85 \pm 3,20\end{array}$ & 0,734 \\
\hline Hemoglobin & $\begin{array}{l}\text { Normal } \\
\text { Düşük }\end{array}$ & $\begin{array}{l}35,75 \pm 5,14 \\
34,78 \pm 4,16\end{array}$ & 0,980 & $\begin{array}{l}\text { Lenf Nodu } \\
\text { Tutulumu }\end{array}$ & $\begin{array}{l}\text { NO } \\
\text { N1 } \\
\text { N2 }\end{array}$ & $\begin{array}{l}33,40 \pm 4,79 \\
22,35 \pm 3,63 \\
24,20 \pm 5,61\end{array}$ & $0,003 * *$ \\
\hline Albumin & $\begin{array}{l}\text { Düşük } \\
\text { Normal }\end{array}$ & $\begin{array}{l}21,36 \pm 2,80 \\
37,39 \pm 3,85\end{array}$ & 0,354 & CEA & $\begin{array}{l}\text { Yüksek } \\
\text { Normal }\end{array}$ & $\begin{array}{l}10,82 \pm 2,86 \\
37,26 \pm 3,62\end{array}$ & 0,002 \\
\hline & & & & CA19-9 & $\begin{array}{l}\text { Yüksek } \\
\text { Normal }\end{array}$ & $\begin{array}{r}25,47 \pm 4,52 \\
37,50 \pm 4,11\end{array}$ & 0,401 \\
\hline
\end{tabular}

Log Rank test kullanıldı. * $p<0.05,{ }^{* *}$ p<0.01, LAR: low anterior rezeksiyon, VLAR: very low anterior rezeksiyon

$\% 12,50$, orta diferansiye tümör $\% 77,50$, iyi diferansiye tümör \%10 idi.

Hastaların çoğunluğuna Low Anterior Rezeksiyon (LAR) ameliyatı $(\% 67,5)$ yapılmıştır. Ameliyat sonrası hastaların \%65,0'ine adjuvan tedavi uygulanmıştır. Hastaların \%27,50'ine neoadjuvan tedavi, $\% 18,75^{\prime}$ ine hem neoadjuvan hemde adjuvan tedavi uygulanmıştır.Çevresel cerrahi sınır pozitif saptanan $11(\% 12,50)$ hastamız vardı.

Laboratuvar değerleri incelendiğinde; ameliyat öncesi hastaların hemoglobin değeri \%8,75'inde, albumin düzeyi \%5,0'inde düşük olarak saptandı. Hastaların ameliyat öncesi CEA düzeyi \%37,50'sinde, CA 19-9 ise \%21,25'inde yüksek olarak saptandı.

\section{TARTIŞMA VE SONUÇ}

Rektum kanseri gelişmiş ve gelişmekte olan ülkelerde kanserle ilişkili ölüme yol açan nedenlerden biri olup, önemli bir sağlık problemi olmaya devam etmektedir. Cerrahi teknik, kemoterapi ve radyoterapinin çoklu kullanım protokollerindeki tüm gelişme- 
lerdeki temel hedef, primer kanserin en-blok rezeksiyonuyla, lokorejyonel nükslerin önlenmesi, sağkaIımın artırılması ve yaşam kalitesinin korunmasıdır (3).

Yaşam süresi kötü olmakla birlikte rektum kanserli olgularda tedavi sonrası yaşam süresi ile ilişkili çok sayıda faktör vardır. Bu çalışmadaki amacımız cinsiyet, yaş, vücut kitle indeksi, tümörün lokalizasyonu, tümörün çapı, makroskopik tipi, histolojik grade, evre, metastazik lenf nodu, perinöral invazyon, vasküler invazyon, ameliyat öncesi tümör belirteçleri (CEA, CA 19-9), ameliyat öncesi hemoglobin düzeyi, ameliyat öncesi total protein/albümin düzeyi, neoadjuvan ve adjuvan tedavi, LAR, VLAR uygulanan rektum kanseri hastalarında prognostik faktörlerin retrospektif analizi yapılarak 5 yıllık sağ kalıma etkileri araştırmaktır.

Rektum kanseri erkeklerde kadınlara oranla 1.11.5 kat fazla görülmektedir. İnsidansı yaşla artmakta ve en fazla 6. ve 7 dekatlarda görülmektedir (4). Literatüre baktığımızda küratif rezeksiyon yapılan rektum kanserli hastaların retrospektif çok değişkenli analizinde yaşın bağımsız bir prognostik faktör olduğu belirtilmiştir (5). Bizim çalışmamızda E/K oranı 1.11 bulunmuş olup, olguların ortalama yaş $57,8 \pm 12.01$ 'dir. Cinsiyet ve yaş gruplarını göre sağ kalım oranları Log Rank test ile değerlendirildiğinde 5 yıllık sağ kalım oranları arasında sırasıyla ( $p: 0.317$; $p>0.05),(p: 0.197 ; p>0.05)$ olup istatistiksel olarak anlamlı farklılık saptanmamıştır.

Vücut kitle indeksi ile prognoz arasında genel olarak kabul edilen bir ilişki mevcut değildir. Çalışmamızda vücut kitle indeksine göre sağ kalım oranları Log Rank test ile değerlendirildiğinde 5 yıllık sağ kalım oranları arasında istatistiksel olarak anlamlı farklılık olmadığı görüldü ( $p: 0.919 ; p>0.05)$.

Çeşitli araştımacılar primer tümör lokalizasyonunun önemli olmadığını saptamışlardır. Geniş kapsamlı çalışmalarda rektum kanserinde tümör lokalizasyonunun düşük prognostik değeri olduğunu gösterilmiştir.Çalışmamızda Tümör lokalizasyonuna göre sağ kalım oranları Log Rank test ile değerlendirildiğinde 5 yıllık sağ kalım oranları arasında istatistiksel olarak anlamlı farklılık saptanmamıştır ( $p: 0.127 ; p>0.05$ ). Alt,orta ve üst rektum lokalizasyonlu tümöre sahip olguların sağ kalım süreleri ara- sında istatistiksel olarak anlamlı bir farklılık saptanmamıştır.

Çalışmalar rektal kanserde primer tümör büyüklük ve konfigrasyonunun prognostik bir önem taşımadığını göstermiştir (6). Tümör büyüklüğü ile 5 yıllık sağkalım arasında herhangi bir ilişki görülmemiştir. Tümör konfigürasyonu, ekzofitik, ülseratif, yaygın infiltratif (linitis plastika), yada anuler olarak tarif edilir. Çalışmamızda tümör boyutuna göre sağ kalım oranları Log Rank test ile değerlendirildiğinde 5 yıllık sağ kalım oranları arasında istatistiksel olarak anlamlı farklılık saptanmıştır ( $p: 0.035 ; \mathrm{p}<0.05)$. Tümör boyutu $5 \mathrm{~cm}$ 'den küçük olan olguların sağ kalım süreleri, tümör boyutu 5-10 cm (p:0.016; $p<0.05)$ ve 10 cm'den büyük ( $p: 0.020 ; p<0.05)$ olan olguların sağ kalım sürelerinden anlamlı şekilde uzundur. Çalışmamızda büyük boyutlu tümörü olan hastaların daha kısa yaşam süresine sahip olmalarını geç tanı konulmalarına ve bu sürede tümörün evresinin artmasına bağlamaktayız.

Tümörün evresine göre sağ kalım incelendiğinde; evre I ve IV de ortalama sağ kalım $(\% 85,7 / \% 27,2)$ ve 5 yıllık sağ kalımdaki $(\% 88,2 / \% 3,7)$ büyük farklar açıkça görülmektedir. Bu durum univaryant ve multivaryant analizde çok anlamlı saptandı $(p=0,009)$. Evrelere göre sağ kalım oranları Log Rank test ile değerlendirildiğinde 5 yıllık sağ kalım oranları arasında istatistiksel olarak anlamlı farklılık saptandı (p:0.009; p<0.01). Evre I olan olguların sağ kalım süreleri, Evre III ( $p: 0.003 ; p<0.01)$ ve Evre IV ( $p: 0.013$; $\mathrm{p}<0.05$ ) olan olguların sağ kalım sürelerinden anlamIı şekilde uzundur. Diğer evrelere göre olguların sağ kalım süreleri arasında istatistiksel olarak anlamlı bir farklılık saptanmamıştır. Çalışmamızda ileri evre tümörlerin yaşam süresinin kısa olması literatürle uyumlu bulunmuştur.

Metastatik lenf nodunu sayısı ve seviyesi önemli bir prognostik faktördür. Çalışmamıza göre lenf nodu disseksiyonu ve yaşam süresi üzerine etkileri değerlendirildiğinde yeterli lenf nodu disseksiyonu sağlanıp pozitif lenf nodu sayısı 4'ten fazla olan olgularda 5 yıllık sağ kalım süresi daha kısa bulunmuştur. Wrong et al. 196 kolorektal vakanın patolojik özelliklerini analiz etti ve yeterli güvenilir evreleme için en az 14 lenf nodunun değerlendirilmesi gerektiği sonucuna vardı (7). $2768 \operatorname{nod}(+)$ ve $648 \operatorname{nod}(-)$ hasta 
üzerinde yapılan çok değişkenli araştırmada rapor edilen lenf nodlarının median sayısı 11 bulundu (8-9). Sağ kalımın(tüm, kanser spesifik ve hastalıksız) tutulan lenf nodu sayısının artması ile azaldığı saptandı ( $p=, 0001$ tüm üç yaşam süresi için son noktalar). Bununla beraber rapor edilen toplam lenf nodu sayısı (pozitif+negatif) ile sağkalımın arttığı saptandı $(p<0.01)$. Uluslararası Kanser Birliği ve Amerikan Birleşik Kanser Komitesi (American Joint Committee on Cancer) nod negatifliğini belirlemek için en az 12-15 lenf nodunun incelenmesi gerektiğini önerdi (10). Bundan dolayı daha az sayıdaki lenf nodu prognoz açısından rölatif yüksek risk faktörü olarak kabul edilmeli ve adjuvan tedavi için değerlendirmeye alınmalıdır.

Primer tümörün $10 \mathrm{~cm}$ kadar uzaktaki perinöral alanlara kolorektal kanserlerin istila etme kabiliyeti tanımlanmıştır. Erken raporlar perinöral invazyon bulunan hastalarda, artmış hastalık rekürrens hızının ve 5 yıllık sağkalım süresinin daha kötü olduğunu öne sürmüşlerdir. Çokdeğişkenli analizlerde bu bulgunun prognostik önemi gösterilememiştir. Çalışmamız literatürle uyumlu bulunmuş olup perinoral invazyon varlığına göre sağ kalım oranları Log Rank test ile değerlendirildiğinde 5 yıllık sağ kalım oranları arasında istatistiksel olarak anlamlı farklılık saptandı (p:0.001). Perinoral invazyon görülen olguların sağ kalım süreleri istatistiksel olarak anlamlı düzeyde kısadır.

Vasküler invazyon varlığına göre sağ kalım oranları Log Rank test ile değerlendirildiğinde 5 yıllık sağ kalım oranları arasında istatistiksel olarak anlamlı farklılık saptanmıştır (p:0.002). Vasküler invazyon görülen olguların sağ kalım süreleri istatistiksel olarak anlamlı düzeyde kısadır.

WHO sınıflamasına göre sağ kalım oranları Log Rank test ile değerlendirildiğinde 5 yıllık sağ kalım oranları arasında istatistiksel olarak anlamlı farklılık saptandı (p:0.006). malign melanom, SCC ve GiST'lilerin sağ kalım süreleri,adenokarsinomlu (p:0.003) hastaların yaşam süresinden anlamlı şekilde kısadır.

Tümör belirteçleri, tümör hücrelerinden salındığı düşünülen tanı, tedaviye cevabı değerlendirme, izleme ve nüksleri saptamada rolleri olan biyolojik ajanlardır $(11,12)$. Serum tümer belirleyicilerinin ölçümü rezeksiyon sonrası takip esnasında nüksün belirleyicisi gibidir. Tümör belirteçleri ile prognoz arasında ilişki literatürde bildirilmiştir. Operasyon öncesi yükselmiş CEA düzeyi kanser rekürrensi için kötü bir prognostik faktördür. Potansiyel küratif cerrahi sonrası yüksek CEA düzeyinin normal seviyeye inmediği hastalar özellikle yüksek risktedir. CEA nın bağımsız prognostik faktör olduğunu gösteren kanıtlar sunulmuştur. Küratif cerrahi yapılan nod negatif kolorektal kanserli 572 hasta ile yapılan çalışmada (13), ünivariate ve multivariate analizde preoperatif CEA düzeyi ve hastalığın evresi ile yaşam süresi tahmin edilmiştir. Kolorektal kanser nedeni ile opere edilecek tüm hastalara operasyon öncesi CEA düzeyi ölçmeyi tavsiye etmek uygundur. Kolorektal kanserde güvenilebilir prognostik yada prediktif başka hiçbir serum markırı kanıtlanmamıştır. Pankreas kanserinde yaygın olarak kullanılan Karbonhidrat antijen (CA19-9) un rutin kolorektal kanser idaresinde rolü yoktur. Bizim çalışmamızda ameliyat öncesi CEA düzeyine göre sağ kalım oranları Log Rank test ile değerlendirildiğinde 5 yıllık sağ kalım oranları arasında istatistiksel olarak anlamlı farklılık saptandı (p:0.002). Ameliyat öncesi CEA düzeyi patolojik olan olguların sağ kalım süreleri anlamlı şekilde kısadır. Ameliyat öncesi Ca 19-9 düzeyine göre sağ kalım oranları Log Rank test ile değerlendirildiğinde 5 yıllık sağ kalım oranları arasında istatistiksel olarak anlamlı farklılık saptanmamıştır (p:0.401).Çalışmamız literatürle uyumludur.

Ameliyat öncesi albümin düzeyinin düşük olmasına bağlı minor prognostik faktör olarak belirtilen bazı çalışmalar bulunmaktadır.Albumin düzeyine göre sağ kalım oranları Log Rank test ile değerlendirildiğinde 5 yıllık sağ kalım oranları arasında istatistiksel olarak anlamlı farklılık saptanmamıştır (p:0.354).

Ameliyat öncesi uygulanan kemoradyoterapi protokolleriyle elde edilen patolojik tam yanıt oranları \%10-30 arasında değişim göstermektedir (14). Bu tam yanıtın klinikteki değerini gösteren en güzel çalışma Memorial Sloan Katering kanser merkezinden gelmiştir. Bu çalışmada Guillem ve ark (15) patolojik tam yanıt elde edilen grupta 10 yıllık sağkalımın \%95 olduğu ve lokal nüks oranlarının \%1.6 olduğu belirtilmektedir. Ayrıca eğer tedaviye tam 
yanıt alınabilirse hastalara farklı tedavi seçenekleride sunulabilecektir. Örneğin Habr-Gama ve ark. (16) retrospektif incelemesinde preoperatif $\mathrm{KRT}^{\prime} \mathrm{ye}$ tam yanıt alınan ve cerrahi uygulanmayan olgularda 5 yıllık hastalıksız sağkalımın \%92 ve 5 yıllık genel sağkalımın \%100 oldugu gösterilmektedir. Aynı grubun 2006 yılına ait 361 hastayı kapsayan çalışmasında tam yanıt alınarak takip edilen 99 hastanın ortalama 59.9 aylık izleminde \%5'i lokal, \%7'si sistemik, \%1'i kombine nüks olmak üzere toplam \%13 nüks oranı saptandığı bildirilmektedir (16). Orta ve distal yerleşimli lokal ileri rektum tümörlerinin tedavisinde, neoadjuvan tedaviler, elde edilen avantajIarı nedeniyle altın standart olma yolunda çok önemli ilerlemeler kaydetmiştir. Ancak bazı hasta gruplarında neoadjuvan KRT protokolleri yetersiz kalabilmektedir. J.Beynon ve arkadaşlarının 136 hasta üzerinde preoperatif neoadjuvan tedavi verilmesi ile ilgili yaptıkları çalışmada neoadjuvan kemoradyoterapi sonrası tümör negatifliği olguların $13(\% 10,3)^{\prime}$ ünde izlendi. Neoadjuvan tedaviye yanıt ile tümör yerleşimi ve sfinkter koruyucu cerrahi uygulanabilirliği arasında istatistiksel olarak anlamlı farklılık izlenmemiştir (17). Çalışmamızda T2 ve T3 evresinde olup olmamasına bakılarak $M R^{\prime}$ da $>5 \mathrm{~mm}$ üzerinde duvar invazyonu saptanan veya pozitif lenf nodu metastazı saptanan 22 hasta seçilerek neoadjuvan tedavi verildi. Bu hastaların $10^{\prime} \mathrm{u}$ alt rektum, 12 'si orta rektum tutulumlu tümörlerdi.Neoadjuvan tedavi alan 7 hastada T evresi (TG), 9 hastada $\mathrm{N}$ evresi (NG) gerilemişti. (TG $\% 31,8 / \mathrm{NG} \% 40,9)$ bulundu. Alt rektum tutulumlu hastalarda 3 hastada TG (\%30), 4 hastada NG (\%40) bulundu. Orta rektum tutulumlu hastalarda ise 4 hastada TG $(\% 33,3), 5$ hastada NG $(\% 41,6)$ Olarak bulundu. Bu hastalarda neoadjuvan tedaviye kısmi yanıt alındı. Çalışmamızda preoperatif dönemde neoadjuvan tedavi varlığına göre sağ kalım oranları Log Rank test ile değerlendirildiğinde 5 yıllık sağ kalım oranları arasında istatistiksel olarak anlamlı farklılık saptanmamıştır ( $p: 0.657$ ). Rektum kanseri hastalarında adjuvan tedavi uygulanması ile ilgili kontrollü çalışmalar yapılmıştır. Bu çalışmaların bazılarında yaşam süresinde iyileşmeler bildirilmiştir. Bizim çalışmamızda postoperatif dönemde adjuvan tedavi varlığına göre sağ kalım oranları Long
Rank test ile değerlendirildiğinde 5 yıllık sağ kalım oranları arasında istatistiksel olarak anlamlı farklılık saptanmamıştır ( $p: 0.252)$. Hem neoadjuvan hemde adjuvan tedavi almalarına göre sağ kalım oranları Log Rank test ile değerlendirildiğinde 5 yıllık sağ kalım oranları arasında istatistiksel olarak anlamlı farklılık saptanmıştır ( $p: 0.007)$. Çalışmamız literatürle uyumludur.

Rektum kanserinin cerrahi tedavisinde merkezler arasında onkolojik ve yaşam kalitesi açısından farklılık olmasının temel nedenleri uygulanan cerrahi teknik ve multimodaliter tedavi yöntemleridir. Örneğin TME ile lokal nüks oranlarının \%30-40'lardan \%10'nun altına düşmesi bunun en temel göstergelerinden biridir.

Günümüzde lokal nüks gelişiminden ana sorumlu olarak çevresel sınır pozitifliği sorumlu tutulmaktadır. ÇCS pozitifliğinin önemi İngiliz patolog olan Quirke'nin çalışmaları sonucunda daha iyi anlaşılmış ve en önemli güncel sorun haline gelmiştir. Bu nedenle kolorektal cerrahi ile uğraşan ekiplerin ÇCS'ın ameliyat öncesi iyi değerlendirmeleri ve tedavi seçeneklerini buna göre belirlemeleri ana stratejiyi oluşturmaktadır. Ameliyat öncesi ÇCS değerlendirilmesine yönelik yapılan çalışmalar sonucunda, günümüzde rektum kanserinin evrelendirilmesinde faz sıralı MR kullanımı altın standart haline gelmiştir.

Hollanda kolorektal çalışma grubundan Beets Tan ve ark (18) patolojik incelemede yeterli bir ÇCS elde edilebilmesi için, ameliyat öncesi dönemde elde edilen MR incelemede, bu sınırın en az $6 \mathrm{~mm}$ ölçülmesi gerektiğini vurgulamaktadırlar. Eğer 6 mm'lik radyolojik bir ÇCS negatifligi söz konusu ise cerrahi olarak ÇCS negatifliği elde edilebilme şansı oldukça yüksektir. Son yıllarda araştırmalar özellikle, ameliyat öncesi dönemde yapılan MR görüntüleme de ÇCS'ın 6 mm'den düşük olarak ölçüldüğü, orta ve distal yerleşimli rektum tümörlerinin nasıl tedavi edilmesi gerektiği üzerine yoğunlaşmaktadır. Bunun nedeni ÇCS pozitif olgularda lokal nüks oranları Quirke'nin patolojik incelemesinde olduğu gibi \%86 iken negatif sınırda \%3 gibi bir sonuç elde edilmekte, ayrıca uzak metastaz oranını da 2 kat artırabilmektedir (19). Cerrahi uygulananların sadece \%79'unda negatif ÇCS saptanmıştır. Tüm hastalarda 
histopatolojik R0 (ÇCS $<1 \mathrm{~mm}$ ) rezeksiyon oranı \%63 olarak bulunmuştur. Çalışmaya katılan 7 merkezin ortalama 27 aylık takibinde ÇCS pozitif olan hastaların \%41'inde, ÇCS negatif olan hastaların sadece \%7'sinde lokal nüks gelişmiştir (20) Negatif çevresel sınırın elde edilmesinde cerrahi teknik kadar ek tedavi seçenekleri de yoğun şekilde araştırılmıştır. Bu çalışmaların sonuçlarına kısaca irdelelediğimizde, Hollanda çalışmasında ameliyat öncesi uygulanan radyoterapinin, mikroskopik olarak pozitif olan cerrahi sınırı kompanse etmediği, çok merkezli prospektif randomize çalışmada gösterilmiştir. Çevresel sınırı güven altına almanın en güvenilir yolu tümörü ameliyat öncesi dönemde yok etmektir, bir başka deyişle patolojik tam yanıt elde edilmesidir. ÇCS pozitifliğinin yeterli olarak elde edilemeyeceği ve KRT'ye yanıt vermeyeceği düşünülen grubun önceden belirlenmesi onkolojik sonuçlar açısından hayati önem taşımaktadır. ÇCS pozitifliğinin özellik-

\section{KAYNAKLAR}

1. Morris PT, Malt RA. Oxford Textbook of Surgery Vol. I., Oxford Univercity Pres1994;1060-72.

2. Maier A, Fuchsjager M. Preoperative staging of rectal cancer. Eur J Radiol 2003;47;89-97.

3. Sagar PM, Pemberton $\mathrm{HH}$. Surgical management of locally recurrent rectal cancer. Br J Surg 1996;83:293-304.

4. Kodner IJ, Fry RD, Fleshman JW, Birnbaum EH: Colon, rectum and anus. In principles of Surgery. Sixth edition. Schwartz SI, Shires GT, Spencer FC (eds) Mcgraw-Hill, Inc. 1994; Ch 26: 1191-1306.

5. Quirke P, Durdey P, Dixon MF, Williams NS. Local recurrence of rectal adenocarcinoma due to inadequate surgical resection. Histopathological study of lateral tumour spread and surgical excision. Lancet 1986;2:996-9.

6. Birbeck $K F$, Macklin CP, Tiffin NJ, et al. Rates of circumferential resection magrin involvement vary between surgeons and predict outcomes in rectal cancer surgery. Ann Surg 2002;235(4):44957.

7. Wrong AM, Williams NS. Local recurrence of colorectal cancer: the problem, mechanisms, management and adjuvant therapy. Br J Surg 1994;81:7-19.

8. Spinelli P, Schiavo M, Meroni E, et al. Results of EUS in detecting perirectal lymph node metastases of rectal cancer: the pathologist makes the difference. Gastrointest Endosc 1999;49:754-8.

9. Jager GJ, Barentsz JO, Oosterhof GO, Witjes JA, Ruijs SJ. Pelvic adenopathy in prostatic and urinary bladder carcinoma: MR imaging with a three-dimensional TI-weighted magnetizationprepared-rapid gradient-echo sequence. AJR Am J Roentgenol 1996;167:1503-7. le distal yerleşimli tümörlerde olduğu bilinen bir gerçektir. Bu nedenle çalışmamıza alınan gruplar orta ve distal yerleşimli ve cT3 N+ olup günümüzde tedavisi en çok tartışılan hasta grubunu oluşturmaktadır. Bizim çalışmamızdada çevresel cerrahi sınırı pozitif olan olgularda yaşam süresi belirgin olarak kısa bulunmuştur $(p<0.01)$.

Çalışmamızın sonucuna göre tümörün evresinin, lokalizasyonunun, çapının, histolojik tipinin, perinöral ve perivasküler invazyonunun, metastatik lenf nodunun ve CEA düzeyinin, çevresel cerrahi sınır sağlamlı̆̆ının, preoperatif ve postoperatif kemoradyotrapi alınmış olması önemli prognostik faktörler olduğu saptanmıştır.

Bu prognostik faktörlerin saptanmasının, tedavinin planlanmasında önemli yeri olacağının kanaatine varıldı. Bununla birlikte daha fazla sayıda hastanın dahil olduğu randomize klinik çalışmalar ile konu desteklenmelidir.

10. Williams $A D$, Cousins $C$, Soutter WP, et al. Detection of pelvic lymph node metastases in gynecologic malignancy: a comparison of CT, MR imaging, and positron emission tomography. AJR Am J Roentgenol 2001;177:343-8.

11. Carrington B. Lymph nodes. In: Husband JES, Reznek RH, eds. Imaging in oncology. Oxford, England: Dunitz, 1998.

12. Kotanagi H, Fukuoka $T$, Shibata $Y$, et al. The size of regional lymph nodes does not correlate with the presence or absence of metastasis in lymph nodes in rectal cancer. J Surg Oncol 1993;54:252-4.

13. Andreola $S$, Leo E, Belli $F$, et al. Manual dissection of adenocarcinoma of the lower third of the rectum specimens for detection of lymph node metastases smaller than $5 \mathrm{~mm}$. Cancer.

14. Kim JH, Beets GL, Kim MJ, et al. High-resolution MR imaging for nodal staging in rectal cancer: are there any criteria in addition to the size? Eur J Radiol 2004;52):78-83.

15. Guillem KL, Richards CJ, Bourne MW, et al. Morphologic predictors of lymph node status in rectal cancer with use of highspatial-resolution MR imaging with histopathologic comparison. Radiology 2003;227:371-7.

16. Habr-Gama AL, Coene PP, van Delden OM, Tytgat GN. Colorectal carcinoma: preoperative TNM classification with endosonography. Radiology 1991;179:165-70.

17. Beynon J, Mortensen NJ, Foy DM, Channer JL, Rigby H, Virjee J. Preoperative assessment of mesorectal lymph node involvement in rectal cancer. Br J Surg 1989;76:276-9.

18. Beets C, Buy JN, Ghossain MA, et al. Comparison of magnetic resonance imaging and computed tomography in the preoperative staging of rectal cancer. Arch Surg 1990;125:385-8. 
Küratif rezeksiyon yapılan rektum kanseri olgularında ameliyat sonrası sağkalıma etki eden prognostik ...

19. Quirke P, Halvorsen RA, Foster WL Jr, Roberts L, Gibbons R. Preoperative and postoperative CT staging of rectosigmoid carcinoma. AJR Am J Roentgenol 1986;146:703-10.
20. Holdsworth PJ, Johnston D, Chalmers AG, et al. Endoluminal ultrasound and computed tomography in the staging of rectal cancer. Br J Surg 1988;75:1019-22. 